Indonesian Journal of Physics and Nuclear Applications

Volume 1, Number 1, February 2016, p. 20-33

ISSN 2549-046X, (C) FSM UKSW Publication

\title{
Basic Principle Application and Technology of Boron Neutron Capture Cancer Therapy (BNCT) Utilizing Monte Carlo N Particle 5'S Software (MCNP 5) with Compact Neutron Generator (CNG)
}

\author{
Aniti Payudan"11, Abdullah Nur Aziz', Yohannes Sardjono² \\ ${ }^{1}$ Jendral Soedirman University, Jl.Prof. Dr. H.R. Boenyamin No.708 Grendeng, Purwokerto and \\ 53122, Indonesia \\ ${ }^{2}$ Center for Accelerator Science and Technology, National Nuclear Energy Agency, $J l$.Babarsari, \\ Yogjakarta and 61011, Indonesia
}

Received: 10 September 2015, Revised: 30 September 2016, Accepted: 26 October 2015

\begin{abstract}
The purpose are to know basic principle, needed component, types of compact neutron generator, plus and minus CNG, identify materials can use as collimator, know physics parameters as input software MCNP 5, knowing step simulation with software MCNP 5, dose in BNCT, knowing boron compound that use in BNCT, getting collimator design for BNCT'S application with source is compact neutron generator and count physics parameter of collimator output and compares it with standard IAEA. Method are reading reference and simulation with MCNP 5 . The result are BNCT use high linear energy transfer from alpha and lithium as a result of ${ }^{10} \mathrm{~B}(\mathrm{n}, \alpha)^{7} \mathrm{Li}$ reaction. BNCT method is effective for cancer therapy. It is not dangerous to normal tissues. To work perfectly, BNCT needs neutron, boron (BSH and BPA as boron compound) Indonesia have study turmeric as boron compound, neutron source, collimator and dose. Dose component in BNCT that important are dose of recoil proton, dose of gamma, dose alfa and dose radiation to environmentally. CNG produce neutron with fussion reaction of deuterium-deuterium $(2,45 \mathrm{MeV})$, deuterium-tritium (14 $\mathrm{MeV})$, tritium-tritium(11,31 MeV) can used as neutron source BNCT. Many kinds of CNG are axial, coaxial, toroidal, plasma design, accelerator design, and CNG with diameter $2,5 \mathrm{~cm}$. CNG have more benefit than another neutron source, make CNG compatible as BNCT application. Neutron from CNG need collimator to get neutron as IAEA's parameter. Material for collimator are wall and aperture (material: $\mathrm{Ni}, \mathrm{Pb}, \mathrm{Bi}$ ), moderator $\left(\mathrm{Al}, \mathrm{Al}_{2} \mathrm{O}_{3}, \mathrm{~S}, \mathrm{AlF}_{3}\right)$, filter $\left({ }^{6} \mathrm{Li},{ }^{10} \mathrm{~B}, \mathrm{LiF}\right.$, $\mathrm{Al}, \mathrm{Cd}-$ nat, $\left.\mathrm{Ni}-60, \mathrm{BiF}_{3},{ }^{157} \mathrm{Gd},{ }^{151} \mathrm{Eu}\right)$, gamma shield $(\mathrm{Bi}, \mathrm{Pb})$. Simulation using MCNP 5 has severally steps, the first is sketching problem, the second is making listing program with notepad, the third open program on visual editor, and the last is running program. Acquired result is design tube collimator with radius $71 \mathrm{~cm}$ and high $139,5 \mathrm{~cm}$. Design contained on lead wall as thick as $19,5 \mathrm{~cm}$; moderate: heavy water as thick as $4 \mathrm{~cm}, \mathrm{AlF}_{3}$ girdle a half of part $\mathrm{CNG}$, $\mathrm{MgF}_{2}(19 \mathrm{~cm}+10 \mathrm{~cm}), \mathrm{Al}(6,5 \mathrm{~cm}+5 \mathrm{~cm})$; Gamma shield: bismuth, and aperture with diameter $6 \mathrm{~cm}$ by steps aside nickel. The result collimator output cross three of five IAEA'S defaults. They are the ratio among dosed gamma with flux epithermal is $5,738 \times 10^{-24} \mathrm{~Gy} . \mathrm{cm}^{2} \cdot \mathrm{n}^{-1}$, the value of ratio among thermal's neutron flux with epithermal neutron is 0,02567 , and ratio among current with flux neutron completely is 1,2 . Need considerable effort of all part to realize $\mathrm{BNCT}$ in Indonesia.
\end{abstract}

Keywords: cancer, BNCT, CNG, collimator, neutron

\section{INTRODUCTION}

Cancer is one of the troublesome non communicable diseases in the world. It is caused by abnormal cells divide without control. This diseases spread quickly to other parts of the body through the blood and lymph systems (NCI, 2009; NCI, no year). Most types of cancer cells eventually form a lump or mass called a tumor, and are named after the part of the body where the tumor originates (American Cancer Society, 2013). Things that trigger cancer are smoking (Kristina, S.A., et al 2014), the wrong diet and poor reproductive factors (Arnold, M. et al 2013). There are several kind of cancer are brain cancer, breast cancer, stomach cancer, liver cancer, lung cancer, leukemia, cancer serviks, rectal cancer, pancreatic cancer, prostate cancer. According

${ }^{1}$ Corresponding author. Email: anitipayudan42@gmail.com 
International Agency for Research on Cancer (2013), the most commonly diagnosed cancers worldwide were those of the lung (1.8 million, $13.0 \%$ of the total), breast (1.7 million, $11.9 \%$ ), and colon rectum (1.4 million, 9.7\%). People that have lung cancer died in United States in 2013 are more than 159 thousand and the number of cancer sufferer increase every year (Saber,A., et al 2015). Cancer have not taken good and fast treatment will made bad effect there also be death. Death rate number because of cancer 2008 to 2030 is predicated increase from eight million to 12 million (Hosmane, N.S., et al 2012). According world health statistic (2014), cancer is in grade six to contribute caused death the years of life lost $n 100.000$ populations in the world on 2000-2012. Data from ministry of public health Indonesia (2013) said that chart of account cancer in Indonesia in 2013 1, 4 \%o. The number of sample is 1.027 .763 (with male: 505.409 and female: 522.354), providable that amount of cancer serviks with female: 522.354; prostate cancer (m: 505.409); another cancer (all age: 1.027.763). The major cancer case is happen in Yogjakarta 4,1 \%o, central java 2,1 $\%$, and Bali $2 \%$. Cancer not only came to old people but also children. In Indonesia, number cancer children increase more or less 6.700 every year (Gunawan, S., et al 2014).

Effective therapy to cancer still is analyzed and is looked for until currently. Expected therapy have tall success zoom criterion, don't wreck normal tissues, and is not impacted negative to human viability. Ordinary therapy type is done for cancer patient are Chemotherapy (NCI, 2009; Barth, R.F., et al 2005; Noble, S., et al 2014; Gorey et al 2014), radiotherapy (NCI, 2009; Barth, R.F., et al 2005; Stupp, R., et al 2005; Saurwein, W., et al 2012), and dissection (NCI, 2009; Wu, J., et al 2015; R. Gonza ' lez Gonza' lez, et al 2012). That therapy not effective because just can increase patient viability as big as $75 \%$ up to a two year and trouble other organ functions, as fall of hair and healthy tissue damage (NCI,2009; Wahyuningsih, 2014). Operate is utilized on early phase therapy, where does tumor be still gets tame character (Abeloff and Martin, 2008). Surgical method or operate can't utterly lift cancer cell.

New threatment type for cancer one is being developed is Neutron Capture Therapy (NCT). Either one NCT what do be analyzed by Badan Tenaga Nuklir Nasional (BATAN) are Boron Neutron Capture Cancer Therapy (BNCT) with Compact Neutron Generator $(\mathrm{CNG})$ as source of neutron. BNCT is looked on as therapy that really keeps faith to therapy cancer (Barth, R.F., et al 2005; Yu, Hui Ting., et al without year; Eskandari, M.R. and Kashian, S., 2009; Sauerwein,W.A.G., and Moss,R.L., 2009; Saurwein, W.A. G, et al 2012; Savolainen, S., et al 2012; Helsinki, 2014). Specifically for therapy raising hell cancer as head and neck cancer(R. Gonza ' lez Gonza ' lez, et al 2012; Yu, Hui Ting., et al without year; Helsinki, 2014), prostate cancer (Yasui,L., et al 2012), oral cancer (Yura, Y. And Fujita, Y., 2013; Heber, E.M., et al 2012; Trivellin,V. A, et al 2004), and breast cancer (Yanagie,H., 2012; Helsinki, 2014; Scorei, I.R., 2011). BNCT constitutes to be damped down radiation that reaction of boron 10 by thermal neutrons so results neglect particles $(\alpha)$, Lithium (Li) and gamma-rays scattering $(\gamma)$, one that gets role in cancer cell desolation (Sauerwein,W.A.G., and Moss,R.L., 2009; Saurwein, W.A. G, et al 2012). Result of this reaction has characteristic Linear Energy Transfer (LET) one that tall (for particle $\alpha$ approaches $150 \mathrm{keV}^{-1} \mathrm{~m}^{-1}$ and for ${ }^{7}$ Li approaches $175 \mathrm{keV} \mathrm{m}^{-1}$ ). Reach of this particle lies on distance 4, $5 \mu \mathrm{m}$ until $10 \mu \mathrm{m}$, so the energy just in single cell (Sauerwein,W.A.G., and Moss,R.L., 2009). This therapy still can't 
yet be applied at Indonesia because still a lot of needed component. To get develops BNCT necessary science which adequately about BNCT and science about Monte Carlo N particle 5 software (MCNP 5), since in BNCT'S research there are many utilize software one of it MCNP 5. So writer chooses title "Basic Principle's Aplication And Technology Boron Neutron Capture Cancer Therapy (BNCT) Utilizing Monte Carlo N Particle 5's Software (MCNP 5) With Compact Generator Neutron (CNG) “.

\section{MATERIALS AND METHODS \\ Materials}

Writing tool as book and pulpen. A set of Personal Computer. Software that is utilized are Microsoft Office Word 2007, Microsoft Office Excel 2007, Search engine Mozilla Firefox, Software MCNP 5, notepad. Indonesian English dictionary. Material as journal and book that gets bearing with BNCT, CNG and MCNP 5.

\section{Methods}

Method those are used is reference and simulation by programs MCNP5.

\section{RESULTS AND DISCUSSION Basic principle BNCT}

Boron neutron capture cancer therapy (BNCT) is a cancer therapy that works by neutron capture reaction $10 \mathrm{~B}(\mathrm{n}, \alpha) 7 \mathrm{Li}$. The reaction of $93.7 \%$ to $\mathrm{He}$ (alpha particles) with an energy of $1.47 \mathrm{MeV}$, Li with energy 0.84 $\mathrm{MeV}$ and $0.48 \mathrm{MeV}$ gamma energy; and the rest is the decay of lithium (6.3\%), which produces alpha with Li and each has an energy of 1.78 $\mathrm{MeV}$ and $1.01 \mathrm{MeV}$. BNCT utilizes ionization energy of alpha particles and lithium to damage the structure of DNA and RNA of cancer cells. A particles effective to kill cancer because actual $\alpha$ particles are helium nuclei, relatively heavier than the other sub-atomic particles. A particle ionization proven as an effective agent, having high linear energy transfer (LET) in the range of $100 \mathrm{KeV} / \mu \mathrm{m}$, and has a very high efficiency to keep on range short tissue $(50-100) \mu \mathrm{m}$.

On BNCT first of all boron compound 10 , can as BSH or BPA was sent to go to cancer cell by concentrates $20 \mu \mathrm{g} / \mathrm{g}$ or $\sim 10^{9}$ atom / cell. Hereafter cancer cell already contain boron 10 at radiation with thermal neutron with energy $0,025 \mathrm{eV}$. On cancer cell that contain boron will happen reaction ${ }^{10} \mathrm{~B}(\mathrm{n}, \alpha){ }^{7} \mathrm{Li}$. Alpha and lithium 7 that ionizing cancer cells so cancer cells will wreck. Alpha particle and result lithium react $\mathrm{BNCT}$ to have transfer energy linear that tall with surrounding reach $10 \mu \mathrm{m}$ (lie within range one cell diameter). So this therapy not wreck healthy tissues because just cancer cell that contain boron who will wreck and alpha particle ionization reach and lithium lies on reach one human cell diameter. At Asia, Country that applied BNCT as therapy cancer are Japan and Taiwan. Indonesia is developing BNCT as a treatment for cancer.

\section{Components BNCT}

BNCT has several components including a boron compound, neutron, neutron source, collimator and dosimetry. Boron compound that has been clinically tested and viable as boron agents there are two BSH (Sodium borocapte) and BPA (p-boronophenylanine). Both of these compounds have proven effective as an agent of boron. Currently in Indonesia are developing boron compounds using white turmeric. This is because the white turmeric can medicate cancer. The research still is developing. Expected white turmeric can be used as effective carrier of the boron compounds. Neutrons are used in BNCT is basically thermal neutrons with energies of $0.025 \mathrm{eV}$. Cancer that is located in the body with a depth of more than $8 \mathrm{~cm}$ can be treated 
with BNCT using epithermal neutrons, will be moderated and when the cancer part into thermal neutron. This is done so that does not need surgery and neutrons can be emitted from outside the patient's body. The quality of neutron beam is used BNCT has five physical parameters, namely the intensity of neutron epithermal must be greater than $1 \times 10^{9} \mathrm{n} / \mathrm{s} \mathrm{cm}^{2}$, the ratio between the dose rate of fast neutrons with a flux of epithermal neutrons value must be smaller than $2 \times 10^{-13} \mathrm{~Gy} \mathrm{~cm}^{2} / \mathrm{n}$, the dose rate gamma / flux of epithermal neutrons smaller than $2 \times 10^{-13} \mathrm{~Gy}$ $\mathrm{cm}^{2} / \mathrm{n}$, the ratio between the flux of thermal and epithermal smaller value of 0.05 and the ratio between the flow of neutrons with total neutron flux is greater than 0.07 . All of which produce neutrons known as the neutron source. Neutron source that can be used there are many nuclear reactors, californium 252, nuclear reactions, accelerators, compact neutron generator, the photo-neutron source, and $\alpha$-beryllium sources. So that the neutrons released by the neutron source can be used for BNCT treatment is needed collimator. Collimator consists of walls, filters, moderator, shielding gamma and aperture. The working principle collimator uses the interaction of radiation with matter. When a material is mashing neutron interaction will occur so that neutrons can be moderated and filtered so that its characteristics meet IAEA standards. Furthermore, dosimetry, dosimetry in BNCT is important to measure the components of boron, neutrons and radiation resulting from the interaction with the material safely used for cancer patients and the surrounding environment.

Some countries use nuclear reactors as a neutron source BNCT. Countries that use nuclear reactors to the facility BNCT has existed in the United States with the reactor MIT (Cambridge, MS), in Japan with the reactor JAERI JRR-4, reactor KUR Kyoto, in Argentina using the reactor Bariloche RA-6 in Taiwan with reactor THOR TRIGA and in Italy by ENEA reactor. One reactor into the reactor Kartini BNCT testing, is the type research reactor TRIGA MARK II (Training, Research and Isotope Production by General Atomic), used for neutron irradiation services and training and research in the field of nuclear technology. Experimental analysis has been done on the physical parameters translucent beam port Kartini's reactor for the preparation of test in vivo and in vitro. The flux of neutrons from the reactor Kartini measured in ring B, ring $\mathrm{C}$ and ring $\mathrm{D}$ are respectively $1.27 \times 1012,1012 \times 1.56$, $1.14 \times 1012 \mathrm{n} \cdot \mathrm{cm}^{-2} \cdot \mathrm{s}^{-1}$. Collimator designing has been done in beam port translucent Kartini's reactor with the following output:

\section{The types of compact neutron generator}

Compact neutron generator (CNG) is producing neutrons by reacting ion source that has accelerated in the accelerator with a target of deuterium or tritium. After colliding, the fusion reaction occurs between the two

Table 1.Output collimator in beam port translucent Kartini's reactor

\begin{tabular}{cccccc}
\hline Name (year) & Sepi & $\frac{\dot{D}_{f}}{\Phi_{\text {epi }}}$ & $\frac{\dot{D}_{\gamma}}{\Phi_{\text {epi }}}$ & $\Phi_{\text {th }} / \Phi_{\text {epi }} \frac{\Phi_{\text {th }}}{\Phi_{\text {ep }} \frac{J}{\Phi_{\text {total }}}}$ \\
\hline $\begin{array}{c}\text { M.I.M. Arrozaqi } \\
\text { (2013) }\end{array}$ & $5,03 \times 10^{8} \mathrm{n} / \mathrm{cm}^{2} \mathrm{~s}$ & $2,17 \times 10^{-13} \mathrm{~Gy} \mathrm{~cm}^{2} / \mathrm{n}$ & $1,16 \times 10^{-13} \mathrm{~Gy} \mathrm{~cm}^{2} / \mathrm{n}$ & 0,120 & 0,835 \\
$\begin{array}{c}\text { Nina Fauziah (2013) } \\
\text { Dwi Wahyuningsih } \\
(2014)\end{array}$ & $7,65 \times 10^{8} \mathrm{n} / \mathrm{cm}^{2} \mathrm{~s}$ & $1,76 \times 10^{-13} \mathrm{~Gy} \mathrm{~cm}^{2} / \mathrm{n}$ & $1,32 \times 10^{-13} \mathrm{~Gy} \mathrm{~cm}^{2} / \mathrm{n}$ & 0,008 & 0,73 \\
\hline
\end{tabular}


fusion's reaction, that occurs between hydrogen isotopes to produce neutrons. In principle there are three types of $\mathrm{CNG}$ is using reaction Deuterium-Deuterium (DD) resulting in neutrons with energies 2, $45 \mathrm{MeV}$, the reaction Deuterium-Tritium (DT) generating neutrons with energy of 14.1 MeV and Tritium-Tritium (TT) produce neutrons with energy $11.31 \mathrm{MeV}$. Compact neutron generator (CNG), which is based on the fusion reaction DD / DT was designed and developed by Lawrence Berkeley National Laboratory (LBNL) (Berkeley, USA). Some types of compact neutron generator developed are axial generator, coaxial, toroidal, neutron generator plasma design, the design of accelerator neutron generator and the neutron generator with a diameter of $2.5 \mathrm{~cm}$. Generator types of axial diameter of $15 \mathrm{~cm}$ and a length of $40 \mathrm{~cm}$ produce neutrons at $108 \mathrm{n} / \mathrm{s}$ is being developed by a group of science Plasma and Ion Source Technology. DD reaction coaxial generator operates with a power of $120 \mathrm{kV}$ and a current of $1 \mathrm{~A}$ and can produce a neutron yield greater than $10^{11} \mathrm{n} / \mathrm{s}$ sent to Turin at the end of 2004. Furthermore this applied at the University of Turin in March 2005. Planning to update the generator EUROSEA DD reaction order produce neutron yield greater than $10^{12} \mathrm{n} / \mathrm{s}$ has been investigated. Compact neutron generator is still investigation.

\section{Advantages and disadvantages of different types of neutron sources}

Nuclear reactors as neutron source in BNCT have some advantages and disadvantages. The advantages of the reactor which reactors are already available in many countries, especially Indonesia has three reactors, so there is no cost for the purchase or procurement of nuclear reactors, the reactor produces high flux allowing use as a source of neutrons BNCT, there are neighboring countries that use the reactor in Japan and Taiwan so as to enable the sharing of knowledge and can be quickly realized in Indonesia. The drawback of nuclear reactors do not have a single energy need to be moderated, nuclear reactor is too large that can not be put in the hospital, Indonesia has a rule that does not allow the therapy is done in a nuclear reactor, it is not possible, the thought of cancer patients on the reactor was creepy when people are ill-treated and should be treated involving the reactor, it can lead to depression and excessive fear. Indonesia will not use nuclear reactor for BNCT therapy in humans, nuclear reactors will only be used to test the in vivo and in vitro.

Californium 252 as a neutron source BNCT has several advantages are have small size, the range of neutron production is $2.3 \times 10^{12}$ neutrons/s for each gram ${ }^{252} \mathrm{Cf}$, already available in Russia, USA, Germany, Japan, and France. Weakness $2.645{ }^{252} \mathrm{Cf}$ short half-life of 2.5 years so every year should change isotopes.

Photo-neutron is a reaction between a photon with an element to produce neutrons. The half-life is usually lower depending on the type of elements. Flux generated is also small, for the reaction $\gamma+{ }^{9} \mathrm{Be}={ }^{8} \mathrm{BE}+\mathrm{n}$ produces $2 \times 10^{6}$ neutrons per second per $\mathrm{Ci}$ of ${ }^{24} \mathrm{Na}$. Photo-neutron source is less suitable for BNCT therapy.

Accelerator is ion accelerating so while interacting with other elements will produce high-energy neutrons. One of the newest accelerators are currently attracting attention for BNCT treatment is cyclotron $30 \mathrm{MeV}$. Cyclotron with particles that are accelerated protons in $30 \mathrm{MeV}$ available at Kyoto University. The advantages of the cyclotron of this type is capable of producing neutrons with high flux, energy is single, focusing neutrons is easier than nuclear reactors for energy is single, neutron yield more, compared with the nuclear reactor it can be put in the hospital, do not pose a radiation hazard to environment, permit the use easier, 
the installation easier, the cost of maintenance is easier, cheaper than having to build a nuclear reactor near the hospital, drawback cyclotron requires material or elements of a target to produce neutrons, because the energy it big to be neutron epithermal needed moderation that great anyway, Cyclotron has dimensions greater than ${ }^{252} \mathrm{Cf}$ and compact neutron generator.

Advantages of compact neutron generator compared to the neutron source other has a smaller size, does not need to be converted into a neutron because the output of $\mathrm{CNG}$ are neutrons, permit easier than the nuclear reactor, can be placed in a hospital, the room size is smaller than the accelerators and nuclear reactors energy neutrons produced by a single character, the energy generated is small so designing collimator $\mathrm{CNG}$ will not be so complicated to produce epithermal neutron appropriate IAEA standards. Shortage of CNG neutron yield produced CNG is still too small, so when moderated and filtered neutron yield at the end of the collimator does not meet the standards of the IAEA, CNG with neutron yield of $10^{12} \mathrm{n} / \mathrm{s}$ is still in the research, isotopes of hydrogen form ion source and the target must always be replaced and it will troublesome.

\section{Characteristics of Material Collimator}

Based on data obtained and a search through the literature, the material can be used as collimators are:

\section{Walls collimator}

The materials required for the collimator wall is a material that can reflect neutrons back, and make stable neutron energy. The material must have the characteristics: the abundance of existing and readily available, high elastic scattering cross section, high total scattering cross section, absorption cross-section of small, relatively large atomic mass, density of large atoms. Materials are as wall collimator are $\mathrm{Pb}$, $\mathrm{Bi}, \mathrm{PbF} 2, \mathrm{BeO}$, Ni.

\section{Moderator}

Material moderator can reduce the energy of fast neutrons into thermal neutrons. The material characteristics are: its abundance in nature a lot, is not readily biodegradable material in high radiation fields, low atomic mass, neutron activation results from the moderator material must have a short life, do not give rise to gamma rays when reacting with neutrons. Recommended materials for these properties are $\mathrm{Al}, \mathrm{Al}_{2} \mathrm{O}_{3}, \mathrm{~S}$, and $\mathrm{AlF}_{3}$.

\section{Filter}

Material Filter is material that can filter fast neutron and thermal neutron but can liberate epithermal neutrons. The material characteristics are: thermal neutron absorption cross section of high, fast neutron absorption cross section is high, inelastic scattering cross section of large, abundant in nature a lot, not give rise gamma rays.

Materials recommended for the filter material is $6 \mathrm{Li} 10 \mathrm{~B}, \mathrm{LiF}, \mathrm{Al}$, Cd-nat, Ni-60, BiF3. 157Gd possibility, 151Eu can be used as thermal neutron filter because it has a thermal neutron absorption cross section which is great.

\section{Shield gamma}

Materials that can be used as a shield gamma is a material with the following characteristics: abundant in any natural, large gamma attenuation, while interacting with neutrons do not emit gamma. Materials that can use are $\mathrm{Pb}, \mathrm{Ti}, \mathrm{Li}$, and $\mathrm{Bi}$.

\section{Aperture}

Materials that can be used as an aperture equal to the material which can be used for reflectors are $\mathrm{Pb}, \mathrm{Bi}, \mathrm{PbF} 2, \mathrm{BeO}$, Ni. Diameter smaller is better. 


\section{Physical Quantities and Units Used in MCNP 5}

MCNP 5 software is the principle method of monte carlo. This software is required for simulating the manufacture of a collimator, dosimetry calculation, modeling cancer, etc. Quantities and standard units used in MCNP 5 are as follows:

- Length (cm),

- Energy (MeV),

- When shaking (10-8 s),

- Temperature, with units of $\mathrm{MeV}(\mathrm{kT}) ; \mathrm{k}=$ 1.3807. $10^{23} \mathrm{~J} / \mathrm{K}$,

- The density of the atoms, the atomic unit / $\mathrm{b} \mathrm{cm}$,

- Mass density, with units of $\mathrm{g} / \mathrm{cm}^{3}$,

- Looks latitude, with units of barns; 1barns $=10^{-24} \mathrm{~cm}^{2}$.

\section{Phase Simulation with MCNP 5}

Step simulation using MCNP 5 software are

1) Creating a design sketch problem.

2) Creating a coding or program listing with notepad, stored in format $\mathrm{i}$.

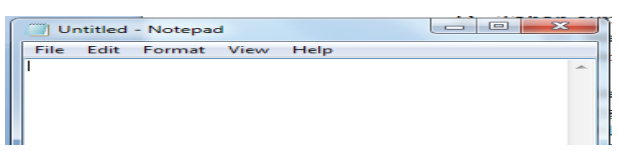

Figure 1.Notepad

3) Run the program in visual editor (vised). Open the file in vised and click update. Figure 2 gives display visual editor (vised).

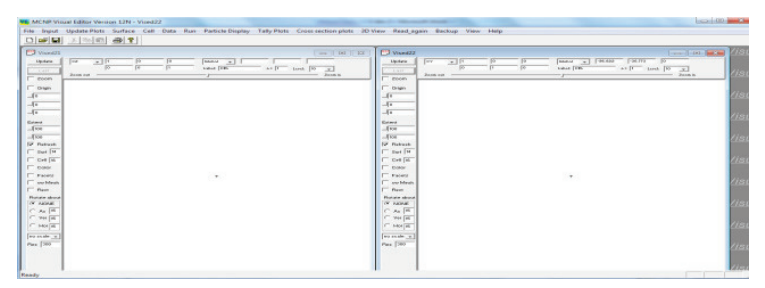

Figure 2.Figure visuals editor (vised).

4) Select taksbar RUN on the top, so it will appear as follows:

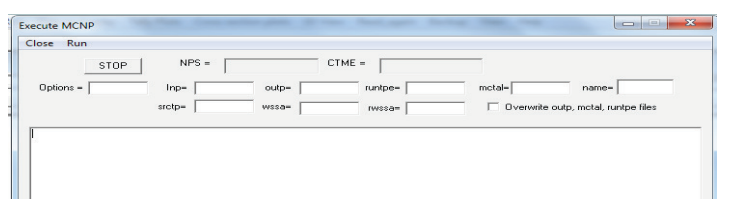

Figure 3.Vised preparation for running

5) Fill Inp column with the input file.

6) Click RUN at the top of the taskbar, the output file will appear in the folder where the input files are located. If the output file will be given another name can be a way to fill out column of the file name ends with a dot o (.o) before running.

\subsection{Making Collimator using MCNP 5 software}

1. The assumptions are:

- Neutron source is a deuterium-deuterium fusion reaction, which produce fast neutrons with energies of $2.45 \mathrm{MeV}$ and shaped point.

- The material used is a material with ideal composition without impurities.

- Neutron yield is $10^{11} \mathrm{n} \mathrm{cm}^{-2} \mathrm{~s}^{-1}$

- Units and scale are used in accordance with MCNP 5 software

2. The material chosen for manufacture of a collimator:

a. Moderator, moderator material chosen $\mathrm{D} 2 \mathrm{O}, \mathrm{Al}, \mathrm{AlF}_{3}, \mathrm{MgF}_{2}$.

b. Shield gamma, gamma shield used is Bismuth.

c. Reflector, reflector used is $\mathrm{Pb}$, Ni $95 \%$.

3. The shape and material composition of collimators

Design collimator is a collimator tube with radius $71 \mathrm{~cm}$ and high 139, $5 \mathrm{~cm}$. Design contained on lead wall as thick as $19,5 \mathrm{~cm}$; moderate: heavy water as thick as $4 \mathrm{~cm}, \mathrm{AlF}_{3}$ girdle a half of part CNG, $\operatorname{MgF}_{2}(19 \mathrm{~cm}+10$ $\mathrm{cm}), \mathrm{Al}(6,5 \mathrm{~cm}+5 \mathrm{~cm})$; Gamma shield: bismuth, 
Aniti Payudan, Abdullah Nur Aziz, Yohannes Sardjono, Basic Principle Application and Technology of Boron Neutron Capture Cancer Therapy (BNCT) Utilizing Monte Carlo N Particle 5 'S Software (MCNP 5) with Compact Neutron Generator (CNG)

and aperture with diameter $6 \mathrm{~cm}$. Design is modified Durisi, et al (2007). With the addition of moderator $\mathrm{D}_{2} \mathrm{O}$, changes in dimensions of space confines of a compact neutron generator and replacement polyethilene with $95 \% \mathrm{Ni}$ on neutron output aperture collimator makes characteristics better.

\section{CONCLUSION AND REMARKS}

1. Boron neutron capture therapy (BNCT) works by neutron capture reaction ${ }^{10} \mathrm{~B}(\mathrm{n}$, a) ${ }^{7} \mathrm{Li}$. The reaction of $93.7 \%$ to He (alpha particles) with an energy of $1.47 \mathrm{MeV}$, Li with energy $0.84 \mathrm{MeV}$ and $0.48 \mathrm{MeV}$ gamma energy; and the rest is the decay of lithium $(6.3 \%)$, which produces alpha with $\mathrm{Li}$ and each has an energy of $1.78 \mathrm{MeV}$ and 1.01 MeV. BNCT utilizes ionization energy of alpha particles and lithium to damage cancer cells by broke DNA, RNA and protein.

2. Components needed in BNCT are neutron, boron compound, neutron source, collimator and dosimetry.

3. Compact neutron generator used in a fusion reaction that there are three, namely $\mathrm{CNG}$ using reaction Deuterium-Deuterium (DD) resulting in neutrons with energies 2, 45 $\mathrm{MeV}$, the reaction Deuterium-Tritium (DT) generating neutrons with an energy of 14.1 $\mathrm{MeV}$ and Tritium-Tritium (TT ) produces neutrons with an energy of $11.31 \mathrm{MeV}$. Some types of compact neutron generator developed ie axial generator, coaxial,

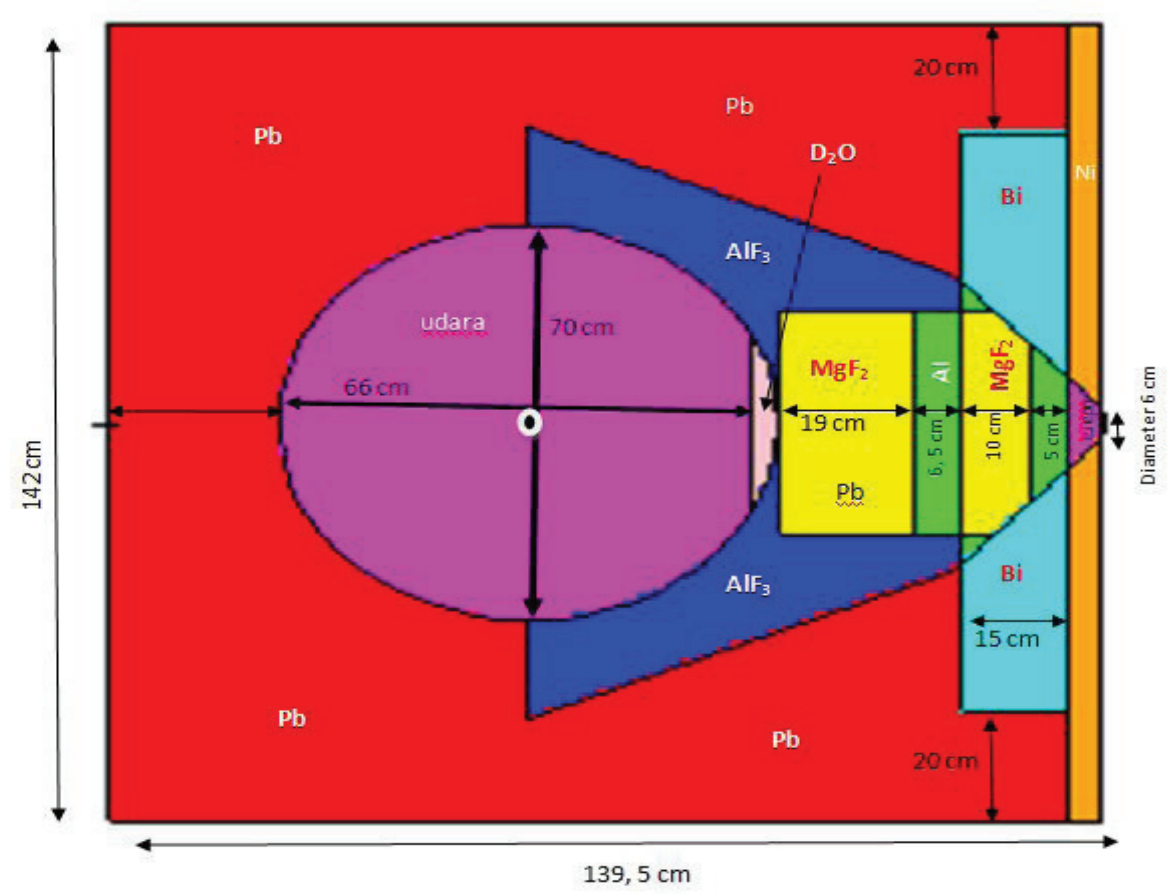

Figure 4.Design collimator proposed

\begin{tabular}{cccccc}
\hline Desain & $\Phi_{\text {epi }}$ & $\mathrm{J} / \Phi_{\text {total }}$ & $\Phi_{t h} / \Phi_{\theta p i}$ & $D_{f} / \Phi_{\theta p i}$ & $D_{\gamma} / \Phi_{\theta p i}$ \\
& $\left(\mathrm{n} / \mathrm{cm}^{2} \mathrm{~s}\right)$ & & & $\left.<\mathrm{Gy} \mathrm{cm}^{2} / \mathrm{n}\right)$ & $\left(\mathrm{Gy} \mathrm{cm}^{2} / \mathrm{n}\right)$ \\
\hline Standar IAEA & $>1 \times 10^{9}$ & $>0,7$ & $<0,05$ & $<2 \times 10^{-13}$ & $<2 \times 10^{-13}$ \\
Durisi et al, 2007 & $1,87 \times 10^{6}$ & 0,61 & - & $18,2 \times 10^{-13}$ & $2,98 \times 10^{-13}$ \\
Desain & $2,6 \times 10^{7}$ & 1,2 & 0,027 & $22,2 \times 10^{-13}$ & $5,499 \times 10^{-24}$ \\
\hline
\end{tabular}


toroidal, neutron generator plasma design, the design of accelerator neutron generator and the neutron generator with a diameter of $2.5 \mathrm{~cm}$.

4. CNG has advantages: smaller so easily be put in the hospital, do not need to be converted into a neutron because the output of CNG has been neutrons, permit easier than the nuclear reactor, the size of the room for a CNG smaller than the accelerators and nuclear reactors, energy neutrons produced is single, the energy generated is small so designing collimator CNG will not be so complicated to produce epithermal neutron appropriate IAEA standards, easier acceptance than the nuclear reactor. The drawback: CNG existing having neutron yield is too small so that when moderated and filtered neutron yield at the end of the collimator does not meet the standards of the IAEA, CNG with neutron yield of $10^{12} \mathrm{n} / \mathrm{s}$ is still in the research, isotopes of hydrogen form ion source and the target must always be replaced and the will be troublesome.

5. Materials that can be used as wall collimator are $\mathrm{Pb}, \mathrm{Bi}, \mathrm{PbF} 2, \mathrm{BeO}$, Ni. Materials that can be used as a moderator are $\mathrm{Al}, \mathrm{Al}_{2} \mathrm{O}_{3}, \mathrm{~S}$, and $\mathrm{AlF}_{3}$. A material recommended for the filter material is ${ }^{6} \mathrm{Li},{ }^{10} \mathrm{~B}, \mathrm{LiF}, \mathrm{Al}, \mathrm{Cd}-n a t$, Ni-60, BiF ${ }_{3}$. Unsure ${ }^{157} \mathrm{Gd}$ and ${ }^{151} \mathrm{Eu}$ can be used as thermal neutron filter because it has a thermal neutron absorption cross section which is great. Materials that can be used as a shield gamma are $\mathrm{Pb}, \mathrm{Ti}, \mathrm{Li}$, and $\mathrm{Bi}$. Materials aperture are $\mathrm{Pb}, \mathrm{Bi}, \mathrm{PbF}_{2}, \mathrm{BeO}$, $\mathrm{Ni}$ with smaller diameter is better.

6. Quantities and units used in MCNP 5 are: Length $(\mathrm{cm})$,

Energy $(\mathrm{MeV})$,

Time shuffle $\left(10^{-8} \mathrm{~s}\right)$,

Temperature, with units $\mathrm{MeV}(\mathrm{kT}) ; \mathrm{k}=$ 1.3807. $10^{23} \mathrm{~J} / \mathrm{K}$,
The density of atoms, the atom units $/ \mathrm{b} \mathrm{cm}$, Mass density, with units $\mathrm{g} / \mathrm{cm}^{3}$,

Cross section, with units barns; 1 1 barns $=$ $10^{-24} \mathrm{~cm}^{2}$

7. Steps simulation using MCNP 5 software is sketched design, coding entries on the notepad, running on vised, select Run, fill the fields Inp with an input file and select RUN again.

8. The dose is considered in BNCT are recoil protons, gamma dose, dose rate and alpha radiation exposure to the environment.

9. Boron compounds already used in BNCT are BSH and BPA. Now Indonesia developing boron compounds with analog white turmeric.

10. Collimator design has been generated for the application of BNCT with compact neutron generator source DD reaction using MCNP program, design a collimator tube with a radius of $71 \mathrm{~cm}$ and $139.5 \mathrm{~cm}$ high. Design composed of a lead wall thickness of 19.5 cm; moderator: $\mathrm{D}_{2} \mathrm{O}$, covers half of the $\mathrm{CNG}$ $\mathrm{AlF}_{3}, \mathrm{MgF}_{2}(19 \mathrm{~cm}+10 \mathrm{~cm}), \mathrm{Al}(6.5 \mathrm{~cm}$ $+5 \mathrm{~cm}$ ); Shield gamma: bismuth, and the aperture diameter of $6 \mathrm{~cm}$ at the edge of the nickel. Neutron output has exceeded three out of five IAEA standards.

\section{ACKNOWLEDGMENT}

Author say thanks to Mr. Sunardi as dean UNSOED that support to us, Susilo Widodo as chief of PSTA-BATAN that give permission to have research in PSTA-BATAN, Yohannes Sardjono as preceptor that give big motivation and provide learning, Mr. Suharyana, Mr. Widarto thanks a lot for all motivation.

\section{Polcy Brief}

Indonesia for cancer therapy used chemotherapy, surgery and radiotherapy. The therapy will have an impact on other parts of the 
body healthy. According the studied conducted by the author, BNCT is a very effective method to cancer treatment and it should be realized in Indonesia. Therefore, the authors requested that the Indonesian republic government support this project until it is completely realized in Indonesia for the prosperity of the people of Indonesia, especially in health.

\section{REFERENCES}

Abeloff, Martin D. Abeloff's Clinical Oncology.4th ed. Philadelphia: Churchill Livingstone, 2008.

Alatas, Z., Hidayati, S., Akhadi, M., Purba,M., Purwadi, D., Ariyanto, S., Winarno, H., Rismiyanto, Sofyatiningrum, E., Hendriyanto, Widyastono, H., Parmanto, E.M., Syahril, tanpa tahun, Buku Pintar Nuklir, BATAN.

Alotiby, Mohammed., 2012, Boron Neutron Capture Therapy for Cancer Treatmens, Disertasi, Univercity Of Surrey.

American Cancer Society. Breast Cancer Facts \& Figures 2013-2014. Atlanta: American Cancer Society, Inc. 2013.

Arnold, M., Karim-Kos H. E., Coebergh J.W., Byrnes G., Antilla, A., Ferlay J., Renehan, A.G., Forman, D., Soerjomataram, I., 2013, Recent Trends In Incidence Of Five Common Cancers In 26 European Countries Since 1988: Analysis Of The European, Cancer Observatory, European Journal of Cancer (2015) 51, 1164- 1187.

Athiqoh, F., Budi, W.S., Anam, C., Tjiptono, T.W., 2014, Distribusi Fluks Neutron Sebagai Fungsi BURN-UP Bahan Bakar Reaktor Kartini, ISSN : 2303-7371.

Baidoo, K.E, Yong, K., Brechbiel, M.W., 2012, Molecular Pathways: Targeted a-Particle Radiation Therapy, Published Online First December 10, 2012; DOI: 10.1158/10780432.CCR-12-0298.
Barth, R.F., Coderre, J.A., Vicente, M.G., dan Blue, T.E., 2005, Boron Neutron Capture Therapy of Cancer: Current Status and Future Prospects, Clin Cancer Res 2005;11:3987-4002.

Barth,R.F., Soloway, A.H., Fairchild, R.G., 1990, Boron Neutron Capture Therapy of Cancer, Cancer Res 1990;50:1061-1070.

Basdevant, J-L., Rich, J., Spiro, M., 2005, Fundamentals In Nuclear Physics, ISBN 0-387-01672-4.

BATAN, 2014, Peraturan Kepala Badan Tenaga Nuklir Nasional Nomor 16 Tahun 2014, BATAN.

Carter, L.L, Schwarz, R.A., no year, MCNP Visual Editor Computer Code Manual. www.mcnp.vised.com. Diakses pada tanggal 12 Pebruari 2003 oleh BATAN.

Ceballos,C., Esposito,J., Agosteo,S., Colautti,P., Conte,V., Moro,D., Pola,A., 2011, Towards The Final BSA Modeling for The Acceleratordriven BNCT facility at INFN LNL, Applied Radiation and Isotopes 69 (2011) 16601663.

Chichester,D.L., dan Simpson,J.D., 2004, Compact Accelerator Neutron Generators, American Institute of Physics.

Copulat, M.E., Minsky, D.M., Kreiner, A.J., 2014, Computational Assessment of Deepseated Tumor Treatment Capability of The ${ }^{9} \mathrm{Be}(d, n)^{10} \mathrm{~B}$ Reaction for Acceleratorbased Boron Neutron Capture Therapy (AB-BNCT). Physica Medica 30 (2014) 133-146.

Durisi,E., Zanini,A., Manfredotti,C., Palamara,F., Sarotto,M., Visca,L., Nastasi,U., 2007, Design of An Epithermal Column for BNCT Based on D-D Fusion neutron Facility, Nuclear Instrument and Method in Physics Research A 574(2007) 363-369.

Eskandari, M.R., Kashian, S., 2009, Design of Moderator and Multiplier Systems for D-T 
Neutron Source in BNCT, Annals of Nuclear Energy 36 (2009) 1100-1102.

Fantidis,J.G., Saitioti,E., Bandekas,D.V., Vordos,N., 2013, Optimised BNCT Facility Based on A Compact D-DNeutron Generator, Int. J. Radiat. Res., October 2013;11(4): 207-214.

Fauziah, N., 2013, A Conceptual Design of Neutron Collimator in The Thermal Column of Kartini Research Reactor for Boron Neutron Capture Therapy, Thesis, Universitas Gadjah Mada, Yogyakrta.

Garabalino, M. A., Hughes, A. M., Molinari, A. J., Heber, E. A., Pozzi, E. C. C., Cardoso, J. E., Colombo, L. Lucas, Nievasm S., Nigg, D. W., Aromando, R. F., Itoiz. M. E., Trivillin, V. A., Schwint, A., 2011, Boron Neutron Capture Therapy (BNCT) for The Treatment of Liver metastases: Biodistribution studies ofboron compounds an experimental model, Radiat Environ Biophys (2011) 50:199-207 DOI 10.1007/s00411-010-0345-6.

Gorey, K.M., Haji-Jama, S., Bartfay, E., Luginnah, I.N., Wright, F.C., Kanjeekal, S.M., 2014, Lack of Access to Chemotherapy for Colon Cancer: Multipicative Disadvantage of Being Exstremely Poor, Inadequately Insured and African American, Health Service Research 2014, 14 :133.

Gritzay, O.O., Kalchenko,O.I., Klimova,N.A., Razbudey,F.V., Sanzhur, A.I., Binney,S.E., 2004, Monte-Carlo Calculations For The Development of A BNCT Neutron Source at The Kyiv Research Reactor, Applied Radiation and Isotopes 61 (2004) 869-873.

Guertin,D.A, Sabatini, D.M., 2005, Cell Size Control, doi: 10.1038/npg.els.0003359.

Gunawan, S., Wolters, E., Dongen, J.V., Ven, P., Sitaresmi, M., Veerman, A., Mantik, M., Kaspers, G., Mostert, S., 2014, Parents' and Health-Care Providers' Perspectives on Side-Effects of Childhood Cancer
Treatment in Indonesia, Asian Pac J Cancer Prev, 15 (8), 3593-3599.

Harmon,C.D., Busch,.R.D., Briesmeister,J., Forster,R.A., 1994, Criticality Calculations with MCNP: A Primer. LA-12827-M Manual.

Heber, E.M., Kueffer, P.J., Lee Jr, M.W., Wawthorne, F., Garabalino, M.A., Molinari, A.J., Nigg, D.W., Bauer, W., Hughes, A.M., Pozi, E.C.C, Trivillin, V.A., Schwint, A.E., 2012, Boron Delivery with liposome for boron neutron capture Therapy (BNCT): Biodistribution studies an experimental model oral cancer demonstrating therapeutic potential, Radiat Environ Biophys (2012) 51:195-204 DOI 10.1007/s00411-0110399-0.

Helsinki, 2014, Neutron Capture Therapy, $16^{\text {th }}$ International Congress, Cancer Society of Finland.

Hosmane, N.S., Maguire, J.A., Zhu,Y., Takagaki,M., 2012, Boron and Gadolinium Neutron Capture Therapy for Cancer Treatment, ISBN-13 978-981-4338-67-7.

IAEA,2012, Neutron Generators for Analytical Purposes, International Atomic Energy Agency Vienna, 2012.

IARC, 2013, Latest World Cancer Statistics Global Cancer Burden rises to 14,1 Million New Cases in 2012: Marked Increase in Breast Cancers must be addressed. International Agency for Reasearch on Cancer.

Ilma, M., 2013, Perancangan Kolimator di Beam Port Tembus Reaktor Kartini untuk Boron Neutron Capture Therapy, Skripsi, Universitas Gadjah Mada, Yogyakarta.

Kato,I., Ono,K., Sakurai,Y., Ohmae,M., Maruhashi,A., Imahori,Y., Kirihata,M., Nakazawa,M., Yura,Y., 2004, Effectiveness of BNCT for Recurrent Head and Neck Malignancies, Applied Radiation and Isotopes 61 (2004) 1069-1073. 
Kemenkes RI, 2013,Riset Kesehatan Dasar 2013, Badan Penelitian dan Pengembangan Kesehatan Kementerian Kesehatan RI.

Kim, S., Min, B.J., Yoon, M., Kim, J., Shin, D. H., Lee, S. B., Park, S. Y., Cho, S., Kim, D. H., 2011, Secondary Radiation Doses of Intensity-modulated Radiotherapy and Proton Beam Therapy in Patients with Lung and Liver Cancer, Radiotherapy and Oncology 98 (2011) 335-339.

Krane, S. Kenneth., 1988, Introductory Nuclear Physics, printed in the United States of America, ISBN 0-471-80553-X.

Kristina, S.A., Thavorncharoensap, M., Pongcharoensuk, P., Montakantikul, P., Suansanae, T., Prabandari, Y.S., 2014, Effectiveness of Tobacco Education for Pharmacy Students in Indonesia, Asian Pac J Cancer Prev, 15 (24), 10783-10786.

Lai, H-W., Chien, S-Y., Kuo, S-J., Tseng, L-M., Lin,H-Y., Chi, C-W., Chen, D.R., 2012, The Potential Utility of Curcumin in The Treatment of HER-2-Overexpressed Breast Cancer: An In Vitro and In Vivo Comparison Study with Herceptin, doi:10.1155/2012/486568.

Liu,Y.-W.H, Huang,T.T, Jiang,S.H., Liu,H.M., 2004, Renovation of Epithermal Neutron Beam for BNCT at THOR, Applied Radiation and Isotopes 61 (2004) 1039-1043.

Lou, T.P, 2003. Compact D-D/D-T Neutron Generators and Their Applications, disertasi, University Of California, Berkeley.

Malik, P., Chaundry, N., Mittal, R., Mukherjee, T.K., 2015, Role Of Receptor For Advanced Glycation End Products In The Complication And Progression Of Various Types Of Cancers, Biochimica et Biophysica Acta 1850 (2015) 1898-1904.

Media Nuklir, 2010, Interaksi Neutron, Diakses dari www.media-nuklir.files.wordpress. com/2010/08/interaksineutron.pdf, 8 Agustus 2014.

Mukawa,T., Matsumoto,T., Nita,K., 2011, Study on Microdosimetry for Boron Neutron Capture Therapy, Progress in Nuclear Science And Technology, Vol. 2, pp.242246 (2011).

Murota, I., dan Obata, T., 2014, Boron Neutron Capture Therapy (BNCT)-Low-Energy Neutron Spectrometer for Neutron Field Characterization, Plasma and Fusion Research: Regular Articles, Volume 9, 4401107 (2014).

NCI, 2009, What You Need To Know About Brain Tumors, U.S. Departement of Health and Human Services, Prancis:National Cancer Institute of Health.

NCI, tanpa tahun, What Is Cancer?, National Cancer Institute at The National Institutes of Health, USA.

NIST, tanpa tahun, www.nist.com. Diakses pada tanggal 15 Agustus 2014.

O'Connor, C.M., Adams, J.U., 2010, Essentials of Cell Biology, Cambridge,MA:NPG Education.

Prevanta, 2012, What is Deuterium?, http://store.preventawater.com/index. php? route $=$ product $/$ category \&path=61_63, diakses pada tanggal 15 Agustus 2014.

R. Gonza'lez-Gonza' lez, R. Bologna-Molina, N. Molina-Frechero, H. R., 2012, Domi'nguezMalagon: Prognostic factors and treatment strategies for adult head and neck soft tissue sarcoma. Int. J. Oral Maxillofac. Surg. 2012; 41:569-575. \#2012, International Association of Oral and Maxillofacial Surgeons. Published by Elsevier Ltd. All rights reserved.

Rasouli, F.S., dan Masoudi,S.F., 2012, Simulation of the BNCT of Brain Tumors Using MCNP Code: Beam Designing and Dose Evaluation, Iran J Med Phys, Vol. 9, No. 3, Summer 2012. 
Razzeti, A., Farias, R.O., Throp, S.I., Trivillin, V.A., Pozzi., E.C.C., Curotto, P., Schwint, A.E., Gonzalez, S.J., 2013, Design, construction and application of a neutron shield for the treatment of diffuse lung metastases in rats using BNCT, Applied Radiation and Isotopes, http://dx.doi. org/10.1016/j.apradiso.2013.12.021.

Reijonen,J., English,G., Firestone,R., Giquel,F., King,M., Leung,K-N., Sun, M.,,tanpa tahun, Compact Neutron Generator Development at $L B N L$, Lawrence Berkeley National Laboratory, Berkeley CA, USA.

Reijonen,J., Lou,T.P., Tolmachoff,B., Leung,K-N., 2001, Compact Neutron Source Development at LBNL, Lawrence Berkeley National Laboratory.

Roda, E., Nion, S., Bernochi, G., Coccini, T., 2014, Blood-brain Barrier (BBB) Toxicity and Permeability Assessment after L-(4${ }^{10}$ Boronopheny)alanine, A Conventional $B$-containing drug for Boron Neutron Capture Therapy, Using An In Vitro BBB Model, Brain Research 1583 (2014) 34-44.

Saber,A., Wekken,A.V.D., Hiltermann, T.J.N., Kok, K., Berg, A.V.D., Groen,H.J.M., 2015, Genomic Aberration Guiding Treatment Of Non-Small Cell Lung Cancer Patients, Cancer TreatmentCommunications(2015) 4, 23-33, elsevier.

Sauerwein,W.A.G., dan Moss,R.L., 2009, Requirements for Boron Neutron Capture Therapy (BNCT) at a Nuclear Research Reactor, EUR 23830 EN - 2009.

Saurwein, W.A.G, Wittig, A., Moss, R., Nakagawa, Y., 2012, Neutron Capture Therapy Principles and Applications, ISBN 978-3-642-31334-9.

Savolainen, S., Kortesniemi, M., Timonen, M., Reijonen, V., Kuusela, L., Uusi-Simola,J., Salli, E., Koivonuro, H., Seppala, T., Lonnroth, N., Valimaki, P., Hyvonen,
H., Kotiluoto, P., Seren, T., Kuronen, A., Heikkinen, S., Kosunen, A., Auterinen, I., 2012, Boron neutron capture therapy (BNCT) in Finland: Technological and physical prospects after 20 years of experiences, Physica Medica (2013) 29, 233e248.

Scorei, I.R., 2011, Boron Compounds in the Breast Cancer Cell Chemoprevention and Chemotherapy, Breast Cancer - Current and Alternative Therapeutic Modalities, Prof. Esra Gunduz (Ed.), ISBN: 978-953307-776-5, InTech, http:/www.intechopen. com/books/breast-cancer-currentandalternative-therapeutic-modalities/boroncompounds-in-the-breast-cancer-cellschemoprevention-andchemotherapy.

Shultis, J.K., Faw, R.E., 2011, An MCNP Primer, Kansas State University, Manhattan.

Siegel, R., Ma, J., Zou, Z., Jemal,A., 2014, Cancer Statistics 2014, CACANCER J CLIN 2014;64:9-29, doi: 10.3322/caac.21208.

Siwi, D.B., 2013, Analisis Dosis Di Organ Kritis Pada Terapi Glioblastoma dengan Boron Neutron Capture Therapy Menggunakan Metode Simulasi MCNP5, Skripsi, Universitas Gadjah Mada, Yogyakarta.

Stupp, R., Masson, W.P., Bent, M.J.V.D., Weller, M., Fisher, B., Taphoom, M.J.B., Belanger, K., Brandes, A.A., Marosi, C., Bogdahn, U., Curschmann,J., Janzer,R., Ludwin, S.K., Gorlia, T., Allgeier, A., Lacombe, D., Cairncross, J.G., Eisenhaur, E., Mirimanoff, R.O., 2005, Radiotherapy Plus Concomitant and Adjuvant Temozolomide for Glioblastoma, N ENGL J MED 352:10.

Trivellin, V.A, Heber, E. M., Itoiz, Nigg, D., Calzetta, O., Blaummann, H., Longhino, J., Schwint, A.E., 2004, Radiobiology of BNCT Mediated by GB-10 and GB$10+B P A$ in Experimental Oral Cancer, Applied Radiation and Isotopes 61 (2004) 939-945. 
Wahyuningsih, D., 2014, Optimasi Desain Kolimator untuk Uji In Vivo Boron Neutron Capture Therapy (BNCT) pada Beam Port Tembus Reaktor Kartini Menggunakan Simulasi Monte Carlo N Particle 5 (MCNP 5), Thesis, Universitas Gadjah Mada, Yogyakarta.

Wang, C.-K Chrris., 2012, Progress in Californium-252 Neutron Brachytherapy, Brachytherapy, Dr. Kazushi Kishi(Ed.), ISBN: 978-953-51-0602-9.

WHO, 2014, World Health Statistic 2014, World Health Organization (WHO).

Wilken, R., Veena, M.S., Wang, M.B., Srivatsan, E.S., 2011, Curcumin: A Review of Anticancer Properties And Therapeutic Activity in Head and Neck Squamous Cell Carcinoma, Molecular Cancer 10:12.

Wu, J., Buggy, D., Fleischmann, E., Parra-Sanchez, I., Treschan, T., Kurz, A., Mascha, E.J., Sessler, D. I., 2015, Thoracic Paravertebral Regional Anesthesia Improves Analgesia After Breast Cancer Surgery: A Randomized Controlled Multicentre Clinical Trial. Can J Anesth/J Can Anesth (2015) 62:241-251, DOI 10.1007/ s12630-014-0285-8.

Wu,Y., Ji,Q., Kwan,J., Leung,K-N., 2008, Recent Developments of Compact Neutron Generators at LBNL, Lawrence Berkeley National Laboratory.
X-5 Monte Carlo Team, 2003, MCNP - A General Monte Carlo N-Particle Transport Code, Version 5 Volume I: Overview and Theory, LA-UR-03-1987.

Yanagie, H., 2012, Application of Neutron Capture Therapy for Locally Reccurent Breast Cancer, DOI 10.1007/978-3-64231334-9_27, (C) Springer-Verlag Berlin Heidelberg 2012.

Yasui,L., Kroc, T., Gladden, S., Androf, C., Bux, S., Hosmane, N., 2012, Boron Neutron Capture in Prostate Cancer Cells, Applied Radiation and Isotopes 70 (2012) 6-12.

Yu, Dihua dan Hung, M-C., 2007, Breast Cancer Chemosensitivity. ISBN:978-0-387740379.

Yu, Hui-Ting., Liu, H.Y., Lin, Tzung-Yi, Wang, Ling-Wei., tanpa tahun, BNCT Treatment Planning of Recurrent Head and Neck Cancer Using THORplan, National Tsing Hua University, Hsinchu, Taiwan, R. O. C. dan Taipei Veterans General Hospital, Taipei, Taiwan, R. O. C.

Yura, Y., Fujita, Y., 2013, Boron Neutron Capture Therapy as a Novel Modality of Radiotherapy for Oral Cancer: Principle and anti tumor effect, Oral Science International 10 (2013) 9- 14. 